\title{
KONTRIBUSI KOMUNITAS HAYU MACA DALAM MENINGKATKAN PENDIDIKAN KARAKTER ANAK USIA DINI DI KOTA CIMAHI
}

\author{
1Marliah, 2Prita Kartika \\ 1,2 IKIP Siliwangi \\ 1marliah3233@gmail.com
}

\begin{abstract}
ABSTRAK
Kontribusi Komunitas Hayu Maca dalam Meningkatkan Pendidikan Karakter Anak Usia Dini di Kota Cimahi. Tujuan dari penelitian ini adalah (1) untuk mengetahui kontribusi yang dilakukan Komunitas Hayu Maca dalam meningkatkan pendidikan karakter anak usia dini, (2) untuk mengetahui bagaimana cara menstimulasi agar anak memiliki sikap moral yang baik melalui kegiatan Komunitas Hayu Maca, (3) untuk mengetahui faktor penghambat dan pendukung kegiatan Komunitas Hayu Maca. Metode yang digunakan pada penelitian ini adalah metode deskriptif. Teknik penelitian yang digunakan adalah wawancara, angket dan observasi. Sumber data penelitian ini adalah anak-anak usia dini yang hadir sebagai peserta di kegiatan Komunitas Hayu Maca sebanyak 20 orang dengan pengelola sebanyak 3 orang. Data penelitian ini dikumpulkan dengan menggunakan instrumen berupa wawancara, pedoman angket dan observasi. Data hasil penelitian diolah dengan menggunakan teknik pengolahan data kualitatif deskriptif dengan teknik presentasi. Hasil penelitian menunjukan 90\% anak memiliki karakter yang baik melalui kegiatan membaca, mendongeng dan berbagi. Dengan kegiatan ini diharapkan generasi selanjutnya akan dapat membangun karakter cerdas melaksanakan intellectual development, psikomotor dan kinesthetic development, affective and creativity development. Berkaitan dengan norma-norma atau nilai yang akan di kembangkan dalam kehidupan sehari-hari. Dengan demikian kegiatan yang mengandung nilai karakter tidak hanya terdapat pada tatanan kognitif, tetapi menyentuh pengalaman nyata di kehidupan sehari-hari, diharapkan nanti menjadi budaya dalam dunia anak. Kegiatan bermain berkelompok di lingkungan outdoor dapat meningkatkan kecerdasan interpersonal dan kecerdasan intrapersonal anak. Dengan demikian dari hasil penelitian dapat disimpulkan bahwa kontribusi Komunitas Hayu Maca dalam meningkatkan pendidikan karakter anak usia dini dapat diterima.
\end{abstract}

Kata kunci : kontribusi, pendidikan karakter, anak usia dini

\section{PENDAHULUAN}

Indonesia memerlukan sumber daya manusia dalam jumlah dan mutu yang memadai sebagai pendukung utama dalam pembangunan. Pendidikan adalah salah satu yang memiliki peranan penting untuk membangun sumber daya manusia. Sesuai dengan UU No 20 tahun 2003 Tentang Sistem Pendidikan Nasional yang meningkatkan keimanan dan ketakwaan serta akhlak mulia serta membentuk karakter dan peradaban bangsa 
yang bermartabat dalam rangka mencerdaskan kehidupan bangsa. Pendidikan nasional bertujuan untuk berkembangnya potensi peserta didik agar menjadi manusia yang beriman dan bertakwa kepada Tuhan Yang Maha Esa, berakhlak mulia, bermartabat, berilmu, cerdas, cakap, kreatif, mandiri dan menjadi warga Negara yang demokratis serta bertanggung jawab terhadap apa yang dilakukan.

Berdasarkan tujuan pendidikan nasional yaitu mencerdaskan kehidupan bangsa jelas bahwa di pendidikan setiap jenjang harus diselenggarakan secara sistematis dan terencana guna mencapai tujuan tersebut.

Pendidikan sebagai hak asasi setiap individu anak bangsa, telah di akui dalam pasal 31 ayat (1) UUD 1945 yang menyebutkan bahwa setiap Negara berhak mendapatkan pendidikan, sedangkan ayat (3) juga menyatakan bahwa pemerintah mengusahakan dan menyelenggarakan suatu sistem pendidikan nasional yang meningkatkan keimanan dan ketakwaan serta akhlak mulia dalam rangka mencerdaskan kehidupan bangsa yang diatur dalam Undang- undang. Oleh karena itu seluruh warga negara baik orang tua, masyarakat maupun pemerintah sendiri bertanggung jawab mencerdaskan bangsa melalui pendidikan. Hal ini menjadi tujuan bangsa Indonesia yang di amanatkan oleh pembukaan UUD 1945 alinea 4.

Menjadi bangsa yang cerdas, tentunya perlu diupayakan bersama, baik secara berkelompok atau perseorangan. Semangat dan motivasi yang muncul dari perseorangan untuk mencedaskan dirinya sendiri akan menjadi modal utama yang menjadi salah satu komponen penting dalam keberhasilan seluruh program yang dicanangkan untuk mencapai tujuan nasional tersebut.

PAUD adalah investasi yang sangat besar bagi keluarga dan bangsa kita, karena PAUD secara tidak langsung dapat membentuk anak Indonesia yang berkualitas yaitu anak yang tumbuh dan berkembang dengan baik sesuai dengan tingkat perkembangannya sehingga memiliki kesiapan yang optimal di dalam memasuki jenjang pendidikan dasar serta dapat mempengaruhi kehidupan di masa dewasanya.

Bermain merupakan dunia anak-anak. Dengan bermain anak- anak dapat mengenal dirinya dan lingkungannya. Di usia prasekolah yaitu usia yang berlangsung antara empat sampai enam tahun merupakan masa awal yang penting yang biasanya disebut dengan masa emas bagi anak-anak untuk merasakan bermain. Bagi anak usia prasekolah bermain adalah hal yang paling mengasyikan dan bermain merupakan kebutuhan pokok bagi anak-anak. Bermain juga dapat menjadi sarana untuk mengembangkan aspek-aspek perkembangan anak seperti nilai agama dan moral, perkembangan aspek kognitif, sosial, emosi, bahasa dan motorik.

Bermain merupakan cara mendasar dan aktivitas yang mampu menyerap dan mengumpulkan dan memproses informasi, belajar keterampilan baru dan berlatih kembali apa yang telah dikuasai. Bermain bagi anak merupakan pelepasan emosional membantu anak untuk mengembangkan harga diri dan menguasai pikirannya. Bermain bagi anak merupakan wahana untuk banyak hal dan mampu menstimulisasi seluruh aspek perkembangan anak. Bermain menjadi salah satu kebutuhan dasar bagi manusia yaitu bagi anak-anak maupun bagi orang dewasa. 
Dari hasil pengamatan di beberapa tempat pendidikan usia dini banyak anak diarahkan untuk menguasai kemampuan akademik sehingga seringkali pendidikan karakter sering diabaikan bahkan dilupakan oleh kebanyakan orang tua. Pendidikan karakter usia dini masih dirasa kurang atau bahkan rendah. Hal ini disebabkan kurang fahamnya para orang tua terhadap pendidikan karakter yang tidak dapat dipisahkan dari kehidupan anak-anaknya yang berusia dini.

Dari aspek pendidikan, stimulasi secara dini sangat diperlukan guna memberikan rangsangan seluruh nilai dan aspek perkembangan anak yang mencakup penanaman nilai-nilai dasar (agama, berakhlak mulia dan budi pekerti), pembentukan sikap (disiplin, tertib dan kemandirian) dan pengembangan pembentukan sikap dasar (motorik, kognitif, dan sosial). Untuk hal tersebut diatas dibutuhkan kegiatan atau aktivitas yang dapat merangsang kemampuan anak seperti simulasi dan bimbingan yang dapat meningkatkan perkembangan karakter anak sehingga menjadi dasar untuk perkembangan anak selanjutnya.

Pada kenyataannya di lapangan masih banyak anak-anak yang memiliki pendidikan karakter yang kurang di masa kecilnya, terlihat dari banyak kejadian yang fenomena seperti perilaku amoral yang melibatkan peserta didik sebagai pelakunya seperti seks pranikah, video porno, penyalahgunaan NAPZA, tawuran, kekerasan dan penghinaan. Hal ini dapat terjadi dikarenakan mereka melihat contoh dari gadget yang di berikan orang tua pada anak-anak yang seharusnya belum perlu menggunakan alat teknologi tersebut. Melalui alat teknologi tersebut informasi apapun akan mudah dapat di akses. Orang tua lebih senang memberikan anak-anak mereka gadget daripada mendampingi anak-anaknya belajar atau sekedar membacakan cerita. Anak-anak menjadi kurang memiliki motovasi untuk membaca buku, atau bersosialisasi dengan lingkungannya, mereka lebih senang main gadget di rumah dan bermain dengan teman dunia maya. Jika hal tersebut terjadi secara terus menerus maka anak-anak akan kehilangan masa untuk bermain dan bersosialisasi dengan lingkungannya atau bahkan dengan teman sebayanya. Fenomena rendahnya minat baca, minat untuk belajar, serta kebutuhan warga untuk lepas dari rutinitas melalui kegiatan yang rekreatif, menggugah sekelompok orang yang peduli sampai akhirnya berinisiatif untuk membuat suatu kegiatan yang menyenangkan bagi keluarga melalui suatu komunitas.

Komunitas ini adalah sebuah lapak baca gratis di Taman Kartini yang diinisiasi oleh Asri Sudarmiyanti dan adik-adiknya. Aktivitas kegiatan ini dilakukan secara terus menerus sejak September 2016. Harapannya adalah agar masyarakat khususnya anak-anak dapat merasakan kesenangan membaca dan koleksi buku pribadinya dapat dimanfaatkan oleh lebih banyak orang. Semangat beliau menggugah sahabatnya, yang juga berprofesi sebagai pendidik untuk turut serta membuat suatu wadah kegiatan yang dapat berkaitan dengan dunia membaca dan literasi.

Sejak bulan Oktober 2016 dibentuklah Komunitas Cimahi Membaca (MaCa) dengan menambahkan kegiatan lain seperti mendongeng, berbagi keterampilan, sharing seputar dunia anak dan pendidikan dalam setiap rutinitas mingguannya.

Berdasarkan pemikiran dan pernyataan diatas peneliti memandang bahwa kegiatan yang dilakukan Komunitas Hayu Maca memiliki peran penting dalam mengembangkan karakter anak usia dini. Berangkat dari pemikiran ini maka peneliti ingin mengetahui 
lebih jauh tentang “ Kontribusi Komunitas Hayu Maca Dalam Meningkatkan Pendidikan Karakter Anak Usia Dini”

\section{KAJIAN TEORI}

A. Konsep Pendidikan Luar Sekolah

Menurut Sudjana (Sudjana, 2001) pendidikan luar sekolah adalah setiap kegiatan belajar membelajarkan yang terorganisasi, sistematis, sengaja dan berkelanjutan, diselenggarakan di luar jalur pendidikan sekolah dengan tujuan untuk membantu para peserta didik dalam mengaktualisasi semua potensi diri berupa kemampuan, pengetahuan, sikap, keterampilan dan aspirasi, yang bermanfaat bagi dirinya, bagi keluarga, bagi masyarakat, bagi lembaga, serta bagi bangsa dan negara.

Pendidikan nonformal dapat menangani kegiatan yang tidak bisa diselenggarakan melalui jalur pendidikan sekolah. Jalur pendidikan nonformal merupakan pendidikan yang diselenggarakan di luar pendidikan formal melalui kegiatan belajar dan mengajar yang tidak harus berjenjang juga berkesinambungan, serta baik yang dilembagakan maupun tidak. Hal ini sejalan dengan pengertian pendidikan nonformal menurut Supardjo Adikusumo dalam (Komar, 2006) pendidikan nonformal adalah setiap kesempatan yang didalamnya terdapat komunikasi yang teratur dan terarah di luar sekolah dan berkesinambungan, dan seseorang memperoleh informasi, pengetahuan, keterampilan dan latihan maupun bimbingan sesuai dengan usia dan kebutuhan hidupnya, dengan tujuan mampu mengembangkan tingkat keterampilan, sikap, dan nilai-nilai yang memungkinkan baginya menjadi peserta yang efesien dan efektif dalam meningkatkan kemampuan diri untuk membangun lingkungan keluarganya bahkan lingkungan masyarakat dan negaranya.

Komunitas Hayu Maca sebagai salah satu bentuk pendidikan luar sekolah yaitu Taman Bacaan Masyarakat. Taman Bacaan Masyarakat sendiri merupakan suatu lembaga yang melayani kebutuhan masyarakat akan informasi melalui ilmu pengetahuan dalam bentuk bahan bacaan dan bahan pustaka lainnya (Kalida, 2012).

Sedangkan fungsi TBM menurut (Kalida, 2012) yaitu menjadi sumber belajar bagi seluruh masyarakat melalui program pendidikan formal dan nonformal, tempat yang memiliki sifat rekreatif melalui bahan bacaan, memperkaya pengalaman belajar masyarakat, menjadi tempat latihan tanggung jawab melalui ketaatan terhadap aturanaturan yang ditetapkan, tempat pengembangan life skill dan sebagainya. Hal diatas sesuai dengan tujuan dari Komunitas Hayu Maca dalam menjalankan semua kegiatannya.

\section{B. Konsep Pendidikan Usia Dini}

PAUD merupakan salah satu bagian dalam bidang pendidikan pada umumnya seperti pendidikan dasar, pendidikan menengah, dan pendidikan tinggi. Anak usia dini sendiri adalah anak-anak dengan rentang usia 0-6 tahun yang merupakan masa emas (golden age) yang harus mendapatkan perhatian maksimal (Rosmawati, 2013). Hal yang membedakan adalah selama masa pendidikan, anak-anak membutuhkan perhatian khusus. Secara fundamental, anak-anak di usia dini berbeda dari orang dewasa, untuk itu mereka perlu dipahami dan dihormati. Terutama berkaitan dengan gaya belajarnya, seperti dengan membiarkan anak "belajar dengan melakukan" dan "belajar dengan 
penemuan" ("learning by doing" and learning by discovery") merupakan tindakan yang penting dalam menghargai atau menghormati anak usia dini Gordon \& Browne, 2011 dalam (Halimah, 2016). Yang harus diperhatikan oleh orang tua dan pendidik dalam membantu tumbuh kembang anak sebaiknya difokuskan pada upaya memenuhi berbagai kebutuhan, diantaranya kebutuhan fisik, kebutuhan psikologi, kebutuhan untuk belajar, kebutuhan untuk dihargai sebagai individu yang mempunyai harga diri (Halimah, 2016).

\section{Hakekat Bermain Pendidikan Anak Usia Dini}

Bermain merupakan kegiatan atau aktivitas yang dilakukan oleh anak agar dapat bereksplorasi dalam mengenal berbagai hal yang ada di lingkungan sekitarnya.. Bermain merupakan aktivitas yang membuat anak dapat mengaktualisasikan diri. Jika anak-anak mempunyai kesempatan untuk bermain atas kemauannya sendiri dan menjadi minatnya dengan berbagai hal yang ada di lingkungan sekitarnya (yang tidak membahayakannya) maka aktivitas bermain dapat melejitkan semua potensinya.

Menurut Hurlock, 1997 dalam (Musfiroh, 2008) bermain adalah suatu aktivitas atau kegiatan yang dilakukan atas dasar suatu kesenangan dan tanpa mempertimbangkan hasil akhir. Kegiatan tersebut dilakukan dengan sukarela, dengan kesadaran tanpa paksaan atau tekanan dari pihak luar. Untuk itu ajaklah anak bermain yang menantang seluruh aspek perkembangannya diantaranya dengan melibatkan secara fisik dan secara intelektual aktif dalam cara yang berkelanjutan.

\section{Lingkungan Belajar Anak Usia Dini}

Maynard dan Waters, 2007 dalam (Halimah, 2016) mengemukakan salah satu keuntungan utama dari penggunaan lingkungan di luar ruangan adalah bahwa lingkungan tersebut menyediakan ruang bagi anak-anak untuk bergerak dengan berbagai gerakan bebas, bermain bersama, telah digambarkan sebagai salah satu cara menerapkan pembelajaran yang paling alami dan sangat penting untuk anak-anak. Ketika di luar kelas anak dapat membangun pengetahuan pada jarak yang lebih besar, menjelajahi dunia secara langsung dan memberikan pengalaman yang sangat kaya, tentang fenomena alam, seperti cuaca, perubahan musim, dan bayangannya. Outdoor bagi anak merupakan tempat untuk terlibat dalam bermain fantasi dan mengembangkan rasa percaya dirinya.

Cara yang paling sederhana dalam menanamkan nilai-nilai karakter dimulai setiap awal kegiatan dengan menyediakan waktu sebanyak lima belas menit sampai dua puluh menit saat anak-anak berada dalam lingkaran. Selama di dalam lingkaran anak-anak diakui dan diberi kesempatan untuk berbagi pengalaman. Kegiatan seperti ini dapat mengasah kecerdasan interpersonal anak. Kecerdasan interpersonal melibatkan kemampuan untuk memahami orang lain dan bekerjasama dengan orang lain. Kecerdasan ini melibatkan banyak kemampuan, yakni mampu merasakan kesedihan orang lain atau berempati pada orang lain, kemampuan mengumpulkan atau mengorganisasi sekelompok orang menuju satu tujuan bersama, kemampuan mengenali dan membaca pikiran orang lain, kemampuan bersosialisasi yang baik atau menjalin kontak menurut Amstrong, 1993:2003 dalam (Musfiroh, 2008).

Anak-anak yang cerdas interpersonal memiliki banyak teman, mereka juga mudah bersosialisasi serta senang terlibat dalam kegiatan atau kerja kelompok.mereka 
menikmati permainan yang dilakukan secara berkelompok. Mereka dengan sukarela memberikan apa yang mereka miliki dan diketahui orang lain termasuk ilmu dan informasi.mereka tampak mengajari teman sebaya tentang sesuatu seperti memilih gambar,memilih warna, bahkan cara bersikap. Amstrong, 1993 dalam (Musfiroh, 2008).

\section{E. Pendidikan Karakter Dalam Pendidikan Anak Usia Dini}

Menurut Stevenson (2006) dalam (Halimah, 2016) karakter adalah pilihan yang baik dan tindakan yang positif, atau berkaitan dengan tingkah laku atau sikap yang benar. Mengenal karakter dengan baik sangat penting karena karakter seseorang mempengaruhi kehidupannya dan mempengaruhi oranglain, dan dunia dalam banyak cara. Karakter adalah tentang pilihan yang baik dan tindakan yang positif. Hal ini tentang hal melakukan yang benar. Karakter menunjukan dirinya dalam perilaku setiap individu. Karakter melibatkan hati nurani, menyentuh penilaian diri, dan pemikiran individu.

Menurut Aunillah, 2011 dalam (Halimah, 2016) pendidikan karakter adalah sebuah metode yang menanamkan nilai-nilai karakter kepada anak yang terdiri dari unsurunsur pengetahuan, kesadaran, individu, tekad, serta adanya kemauan dan kesadaraan serta tindakan untuk melaksanakan nilai-nilai kebaikan tersebut, baik terhadap Tuhan Yang Maha Esa, trhadap diri sendiri, terhadap sesama manusia, terhadap lingkungan atau bangsa, sehingga akan terwujud insan yang beriman dan bertakwa.

Menurut Abidin, 2012 dalam (Abidin, 2012) mengemukakan bahwa pendidikan karakter dimaknai sebagai pendidikan yang mengembangkan nilai-nilai karakter dan sikap pada diri anak-anak sehingga mereka memiliki nilai dan karakter yang baik sebagai karakter dirinya, menerapkan nilai-nilai baik tersebut dalam kehidupan dirinya, sebagai anggota masyarakat, dan sebagai warga negara yang religius, mandiri, produktif, dan kreatif.

\section{METODE PENELITIAN}

Pendekatan dan Jenis Penelitian

Penelitian ini menggunakan pendekatan kualitatif dengan jenis deskriptif. Dalam penelitian deskriptif data yang dikumpulkan berupa kata-kata hasil wawancara, gambar dan bukan angka-angka. Oleh karena itu penelitian ini akan sebagian berisi hasil wawancara untuk memberi gambaran penyajian laporan tersebut. Data tersebut berasal dari naskah wawancara, observasi, foto, video, dokumen pribadi, catatan atau memo dan lainnya.

Penelitian kualitatif memperoleh kata-kata perilaku dan selebihnya adalah data tambahan seperti dokumen, catatan dan lain-lain, kata-kata dan perilaku orang yang diamati, diwawancara dan terdokumentasi merupakan sumber data utama serta dicatat melalui catatan tertulis atau melalui perekaman video, pengambilan foto atau dokumentasi.

Penelitian deskriptif tidak memberikan perlakuan manipulasi atau perubahan pada variable- variable bebas yang akan diteliti, namun menggambarkan suatu kondisi nyata dengan apa adanya. Alasan menggunakan penelitian kualitatif deskriptif karena peneliti ingin mendeskripsikan atau menggambarkan suatu kondisii nyata dengan apa adanya 
tentang praktek pelaksanaan pendidikan karakter melalui kegiatan yang diadakan Komunitas Hayu Maca Cimahi.

Kehadiran Peneliti Dalam bagian ini perlu disebutkan bahwa peneliti bertindak sebagai instrument sekaligus pengumpul data. Instrument manusia juga dapat pula digunakan tetapi fungsinya terbatas sebagai pendukung tugas peneliti. Oleh karena itu kehadiran peneliti dilapangan untuk penelitiam kualitatif mutlak diperlukan. Peneliti sendiri yang terjun ke lapangan dan terlibat langsung dalam observasi dan juga wawancara dengan pihak- pihak yang bersangkutan dalam penelitian.

Teknik Pengumpulan Data Penelitian apapun mengharuskan adanya validasi data guna memperoleh data-data yang akurat yang dibutuhkan dalam penelitian ini, maka dibutuhkan pengumpulan data terkait. Dalam hal ini membutuhkan beberapa teknik maka penelitian menggunakan beberapa teknik pengumpulan data sebagai berikut:

Wawancara merupakan salah satu bentuk teknik pengumpulan data yang banyak digunakan dalam setiap penelitian deskriptif kualitatif maupun penelitian deskriptif kuantitatif. Wawancara dilakukan secara lisan dan pertemuan tatap muka secara individual, menggunakan wawancara yang berbentuk pertanyaan-pertanyaan. Wawancara yang dilakukan bertujuan untuk mengetahui hambatan dan pendukung yang dialami pengelola dalam melaksanakan kegiatan dan upaya-upaya yang akan dilakukan oleh pengelola selama ini.

Angket merupakan suatu teknik atau cara pengumpulan data secara tidak langsung (peneliti tidak langsung bertanggung jawab dengan responden). Instrumen atau alat pengumpulan datanya juga disebut angket berisi sejumlah pertanyaan atau pernyataan yang harus dijawab atau direspon oleh responden. Sama dengan pedoman wawancara, pada teknik angket ini bentuk pertanyaan bisa bermacam-macam, yaitu pertanyaan terbuka, pertanyaan berstruktur, dan pertanyaan tertutup. Teknik pelaksanaan ini dibacakan oleh peneliti atau dibantu orangtuanya.

Observasi Menurut (Syaodih, 2010) observasi atau pengamatan merupakan suatu teknik atau cara mengumpulkan data dengan jalan mengadakan pengamatan terhadap kegiatan yang sedang berlangsung. Apabila peneliti sudah menentukan kriteria yang diamati, maka selanjutnya peneliti tinggal menghitung saja berapa kali jawaban,dan tindakan atau sikap anak yang sedang diteliti itu ditampilkan. Observasi ini dilakukan untuk memantau proses dan dampak kegiatan yang dilaksanakan Komunitas Hayu Maca untuk meningkatkan pendidikan karakter anak yang diperlukan untuk dapat menata langkah- langkah perbaikan yang akan dilakukan sehingga menjadi efektif dan efesien.

Studi Dokumentasi Studi dokumentasi merupakan suatu teknik pengumpulan data dengan menghimpun, mengumpulkan dan menganalisis dokumen-dokumen, baik dokumen tertulis, gambar maupun elektronik. Dokumentasi yang digunakan adalah foto-foto kegiatan Komunitas Hayu Maca dalam setiap siklus kegiatan. Selain foto-foto kegiatan, dokumentasi yang digunakan adalah profil lembaga, profil pengurus dan kegiatannya.

Prosedur pengolahan data merupakan proses yang sangat penting, oleh karena itu harus dilakukan secara benar. Data yang dikumpulkan kemudian diolah, yang termasuk 
dalam kegiatan pengumpulan data ialah penghitungan frekuensi dan prosentase dari setiap jawaban kemudian memberikan penafsiran nilai prosentase yang diperoleh.

Adapun tahap pengolahan data dalam penelitian adalah meliputi:

a. Penyuntingan, pada bagian ini seluruh daftar data pertanyaan kemudian diperiksa dan dikelompokkan berdasarkan pembagiannya;

b. Penyusunan dan penghitungan data, penghitungan awalnya dilakukan dengan secara manual kemudian menggunakan alat bantu komputer;

c. Tabulasi, data yang telah disusun dan di hitung secara manual selanjutnya disajikan dalam bentuk tabel. Pembuatan tabel tersebut dilakukan dengan cara tabulasi langsung. Karena data langsung dipindahkan dari kuisioner ke kerangka tabel yang telah disiapkan tanpa proses perantara lainnya.

Menurut (Hasan, 2008) menggunakan analisa kualitatif dengan skala pengukuran sebagai berikut:

1. $75 \%-100 \%$ berarti tinggi

2. $50 \%-74,9 \%$ berarti sedang

3. $25 \%-49,9 \%$ berarti rendah

4. $0 \%-24,9 \%$ berarti sangat rendah.

Dalam penelitian ini analisis data yang digunakan adalah analisis kualitatif yaitu analisis yang digunakan ini untuk mengolah data yang dapat di klasifikasikan serta diukur dan dalam bentuk angka. Analisis data adalah pengolahan data yang diperoleh dengan menggunakan rumus atau dengan aturan-aturan yang ada sesuai dengan pendekatan penelitian. Metode ini digunakan untuk mengetahui presentase hasil kegiatan Komunitas Hayu Maca terhadap pendidikan karakter anak usia dini. Adapun rumus yang digunakan adalah sebagai berikut:

Keterangan:

$$
\mathrm{P}=\frac{F}{N} \times 100 \%
$$

P: Prosentase

F: Jumlah skor yang didapat

$\mathrm{N}$ : Nilai presentasi atau hasil.

Distribusi frekuensi adalah data-data yang telah diperoleh dari hasil suatu penelitian.

\section{PEMBAHASAN}

Nama Kegiatan Dalam rangka meningkatkan minat baca masyarakat ini dan meningkatkan pendidikan karakter anak usia dini, maka dicanangkan bahwa kegiatan ini bernama "Gerakan Hayu Maca"

Kegiatan ini telah dimulai dengan membuka lapak baca gratis dengan kegiatan membaca, menggambar, dan mewarnai sejak bulan September 2016. Kegiatan lapak baca ini kemudian di buat beragam sejak bulan oktober 2016. Selain membaca dan mewarnai juga dilengkapi dengan kegiatan mendongeng dan berbagi pengetahuan dan keterampilan.

Waktu pelaksanaan Gerakan Hayu Maca dilakukan secara rutin setiap Hari Minggu Pukul 08:00-13:00 WIB bertempat di Taman Kartini Cimahi. 
Ragam Kegiatan Kegiatan inti antara lain

Membaca di lapak bacaMaca membuka lapak gratis di Taman Kartini, salah satu taman yang berada di kota Cimahi. Lapak baca dilengkapi dengan berbagai macam koleksi bacaan, agar bisa dimanfaatkan oleh warga dengan latar belakang berbagai jenjang pendidikan yang berbeda dan usia. Buku yang disediakan merupakan milik Komunitas Cimahi membaca yang di peroleh dari para donatur. Buku hanya boleh dibaca di lapak baca dan tidak boleh dibawa pulang.

Pengunjung lapak baca di damping oleh beberapa volunteer yang dengan senang hati membantu para balita dan TK untuk mengenalkan keterampilan literasi.

Mendongeng Selain membaca, untuk menarik minat warga dan untuk meramaikan ruang publik di Cimahi, Komunitas MaCa menggelar kegiatan mendongeng. Mendongeng diharapkan dapat meningkatkan rasa penasaran anak akan suatu cerita. Dongeng yang disampaikan diambil dari buku yang ada di lapak baca, sehingga menarik minat anak untuk mencari tahu keseluruhan cerita yang didengarkannya. Selain untuk meningkatkan minat baca, mendongeng bisa menjadi sarana hiburan dan penanaman nilai- nilai positif.

Dongeng melibatkan audience anak untuk menjadi pemeran tokoh cerita, dilengkapi property drama yang unik, sehingga lebih menarik minat pengunjung dan juga menjadi ajang untuk melatih kepercayaan pada diri anak.

Menggambar, Berkreasi dan Booth permainan. Menggambar, mewarnai, bermain fuzzle, flash card, lego, dan ular tangga akhlakul karimah berukuran jumbo selalu mereka sediakan bersamaan dengan kegiatan membaca. Selain mengasah keterampilan motorik halus dan motorik kasar, kegiatan ini pun diadakan bagi anak yang belum mengenal huruf atau bagi anak- anak yang mencari aktivitas lain selain membaca.

Wanci babagi ( saatnya Berbagi)

Bedah buku Mereka mengundang para pengarang yang telah berhasil menerbitkan buku- buku atau terkait di bidangnya, untuk berbagi tentang buku yang mereka tulis serta berbagi tips kesuksesan mereka dalam berkarya.

Forum sharing dan diskusi Kegiatan ini menjadi wadah berbagi pengalaman dan atau pengetahuan di kalangan pengunjung lapak maca. Topik yang di bahas bisa sangat beragam, namun tetap ditentukan tema yang' bergizi dan up to date'.

Pelatihan keterampilan Selain kegiatan sharing atau diskusi yang dipandu oleh para praktisi / pakar, sesekali mereka mengadakan demo keterampilan seperti memasak, membuat karya, teknik berkebun hidroponik, dan lain- lain yang bisa menambah pengetahuan masyarakat dan menambah penghasilan keluarga.

Book Charity Selain mengumpulkan buku untuk MaCa sendiri, MaCa juga mencanangkan program rutin berbagi buku kepada perpustakaan atau taman bacaan di sekitar Cimahi. Upaya penggalangan buku dilakukan dengan dua acara yaitu Menyediakan drop box ( kotak sumbangan buku) setiap kali MaCa membuka lapak baca di Taman Kartini

Mengadakan event- event khusus yang bertujuan untuk mengumpulkan buku dari peserta atau pengunjung disamping menumbuhkembangkan minat dan keterampilan literasi. 
Dalam menanamkan upaya penanaman karakter kepada anak, gambaran sifat karakter pada anak dapat ditemukan dalam biografi atau buku fiksi sejarah. Biografi memberikan kredibilitas terhadap pentingnya membangun karakter positif. Salah satu cara menggunakan buku yang memuat tokoh yang memiliki sifat karakter tertentu. Buku dapat dibacakan atau jika anak-anak sudah dapat membaca, mereka dapat membaca sendiri.

Buku-buku cerita yang mengandung tokoh-tokoh yang menampilkan nilai-nilai karakter yang akan ditanamkan kepada anak. Sebuah buku dapat mengubah pengalaman hidup setiap individu, menanamkan nilai-nilai karakter baik pada anak melalui literatur dapat membangkitkan imajinasi moral yang bertujuan untuk memberikan pemahaman teoritis dan praktis melalui satra naratif dalam mengungkapkan pertumbuhan dan kemerosotan moral menurut Bohlin, 2005 dalam (Halimah, 2016).

Kegiatan mendongeng interaktif ini dapat menstimulasi kecerdasan intrapersonal anak. Kecerdasan interpersonal berkaitan dengan aspek internal yaitu kemampuan mengolah emosi dalam diri seseorang seperti perasaan hidup, rentang emosi, kemampuan untuk membeda-bedakan emosi, menandainya dan menggunakannya untuk memahami dan membimbing tingkah laku sendiri. Hal ini sejalan dengan kegiatan mendongeng yang diselenggarakan Komunitas Hayu Maca dalam meningkatkan pendidikan karakter anak usia dini.

Kecerdasan intrapersonal akan senantiasa terasah karena ketika bermain anak mengeksplorasi emosi yang berbeda (marah, sedih, takut)dan peran sosial yang berbeda pula dalam permainan mereka. Anak-anak dengan kecerdasan intrapersonal yang baik akan terlihat lebih mandiri dari anak lain, memiliki kemauan yang keras atau teguh pendirian, penuh percaya diri, memiliki tujuan-tujuan tertentu. Awal masa pertumbuhan dan perkembangan anak-anak merupakan saat yang menentukan bagi perkembangan intrapersonal. Anak-anak yang memperoleh kasih sayang, pengakuan, dan tokoh panutan cenderung mampu mengembangkan kosep diri yang positif dan mampu membentuk citra diri sejati. Menurut Amstrong, 1993 dalam (Musfiroh, 2008).

Kegiatan Komunitas Hayu Maca dilaksanakan di taman terbuka atau biasa disebut lingkungan outdoor, karena pada umumnya tempat bermain yang menjadi favorit anak adalah lingkungan outdoor. Selain itu lingkungan outdoor juga mampu menstimuli seluruh aspek perkembangan dan pertumbuhan anak, bahkan nilai-nilai karakter sangat memungkinkan ditanamkan lebih kuat pada saat anak-anak bermain dan berada di lingkungan outdoor. Seperti yang dikemukakan Cook and Heseltine dalam (Halimah, 2016) bahwa daerah outdoor adalah lingkungan belajar yang lengkap yang melayani semua kebutuhan anak, baik kebutuhan untuk pengembangan kognitif, linguistik, emosional, sosial dan fisik. Di outdoor, anak-anak memiliki ruang yang lebih luas, memiliki kebebasan, mendapatkan udara segar, dan waktu untuk bekerja sesuai dengan kepentingan mereka. Lebih banyak anak melakukan aktivitas di outdoor, anak akan mendapatkan banyak peluang untuk mengambil resiko dan menjadi sukses daripada lingkungan indoor. Lingkungan outdoor mampu memberikan peluang yang kaya untuk membangun kebugaran fisik dan memberikan banyak kesempatan pada anak untuk belajar, pengalaman berharga dan menjadi kurang efektif jika hanya diberikan di indoor. 


\begin{tabular}{|c|c|c|c|c|}
\hline Pernyataan & $\begin{array}{l}\text { Menyukai } \\
\text { kegiatan ini }\end{array}$ & $\begin{array}{c}\text { Senang } \\
\text { membaca } \\
\text { buku }\end{array}$ & $\begin{array}{c}\text { Senang } \\
\text { bermain } \\
\text { disini } \\
\end{array}$ & $\begin{array}{c}\text { Mengenal } \\
\text { teman di } \\
\text { samping } \\
\end{array}$ \\
\hline Ya & $90 \%$ & $75 \%$ & $90 \%$ & $50 \%$ \\
\hline Tidak & $10 \%$ & $25 \%$ & $10 \%$ & $50 \%$ \\
\hline Pernyataan & $\begin{array}{l}\text { Berkenalan } \\
\text { dengan } \\
\text { teman baru }\end{array}$ & $\begin{array}{c}\text { Menyapa saat } \\
\text { bertemu } \\
\text { mereka } \\
\text { kembali }\end{array}$ & $\begin{array}{c}\text { Membantu } \\
\text { teman yang } \\
\text { kesulitan } \\
\text { mencari buku }\end{array}$ & $\begin{array}{c}\text { Sabar } \\
\text { menunggu } \\
\text { giliran } \\
\text { membaca } \\
\text { buku } \\
\end{array}$ \\
\hline Ya & $90 \%$ & $60 \%$ & $90 \%$ & $85 \%$ \\
\hline Tidak & $10 \%$ & $40 \%$ & $10 \%$ & $15 \%$ \\
\hline Pernyataan & $\begin{array}{c}\text { Mau } \\
\text { berbagi } \\
\text { dengan } \\
\text { teman baru } \\
\end{array}$ & $\begin{array}{c}\text { Menangis } \\
\text { saat tidak } \\
\text { didampingi } \\
\text { orangtua } \\
\end{array}$ & $\begin{array}{c}\text { Senang } \\
\text { memiliki } \\
\text { teman baru }\end{array}$ & $\begin{array}{c}\text { Menyimpan } \\
\text { buku ke } \\
\text { tempat } \\
\text { semula } \\
\end{array}$ \\
\hline Ya & $90 \%$ & $80 \%$ & $90 \%$ & $75 \%$ \\
\hline Tidak & $10 \%$ & $20 \%$ & $10 \%$ & $25 \%$ \\
\hline Pernyataan & $\begin{array}{l}\text { Merapikan } \\
\text { buku yang } \\
\text { tidak rapi }\end{array}$ & $\begin{array}{c}\text { Senang } \\
\text { mendengarkan } \\
\text { dongeng }\end{array}$ & $\begin{array}{c}\text { Suka } \\
\text { bercerita }\end{array}$ & $\begin{array}{c}\text { Senang } \\
\text { mewarnai }\end{array}$ \\
\hline Ya & $70 \%$ & $90 \%$ & $65 \%$ & $80 \%$ \\
\hline Tidak & $30 \%$ & $10 \%$ & $35 \%$ & $20 \%$ \\
\hline \multicolumn{2}{|c|}{ Pernyataan } & enang menggam & \multicolumn{2}{|c|}{ Senang bermain puzzle } \\
\hline \multicolumn{2}{|c|}{ Ya } & $65 \%$ & \multicolumn{2}{|r|}{$80 \%$} \\
\hline \multicolumn{2}{|c|}{ Tidak } & $35 \%$ & \multicolumn{2}{|r|}{$20 \%$} \\
\hline
\end{tabular}

Berdasarkan analisis data dengan menggunakan tabel frekuensi, maka penulis melakukan pertanyaan penelitian yaitu dengan menghitung seberapa besar pengaruh kontribusi Komunitas Hayu Maca melalui kegiatan yang diselenggarakannya untuk meningkatkan pendidikan karakter anak usia dini di Kota Cimahi. Melalui penghitungan tertinggi 90\% memiliki karakter baik dan menyukai kegiatan yang diselenggarakan oleh Komunitas Hayu Maca yaitu kegiatan bermain, mendongeng dan berbagi banyak berpengaruh terhadap pendidikan karakter anak terlihat dari hasil observasi pada hari minggu tanggal 25 februari 2018. Dengan demikian karena terdapat pengaruh yang signifikan, maka dapat disimpulkan bahwa kontribusi Komunitas Hayu Maca dalam meningkatkan pendidikan karakter anak usia dini di Kota Cimahi dapat diterima 


\section{PENUTUP}

Berdasarkan hasil penelitian yang dilakukan pada kegiatan Komunitas Hayu Maca, maka peneliti mengemukakan simpulan tentang kontribusi Komunitas hayu Maca dalam meningkatkan pendidikan karakter anak usia dini di kota Cimahi sebagai berikut:

1. Kontribusi Komunitas Hayu Maca dalam meningkatkan pendidikan karakter anak usia dini adalah dengan mengadakan berbagai kegiatan seru seperti membuka lapak baca, bermain, mendongeng dan berbagi setiap minggu di lingkungan terbuka yaitu Taman Kartini.

2. Cara menstimulasi anak agar memiliki sikap moral yang baik melalui kegiatan membaca buku-buku cerita anak yang menggambarkan sosok tokoh cerita, mendongeng atau bercerita dengan menyampaikan cerita yang mengandung unsur nilai-nilai keteladanan dan pemberian wawasan yang dilakukan secara lisan. Panca indra merupakan pintu masuk bagi seluruh input yang masuk ke dalam pusat kecerdasan otak anak yang artinya apapun yang anak lihat, dengar dan rasakan akan masuk ke dalam otak dan memori anak. Setiap anak belajar tentang sikap dan kepribadian dari orang-orang yang mengasuh. Sehingga anak juga dapat belajar dari apa yang dilihat di berbagai media seperti televisi, radio, dan internet pun menjadi salah satu faktor pembentukan otak anak. Berdasarkan hasil angket yang terdiri dari 18 pertanyaan dan bertujuan untuk mengetahui karakter anak yang dapat diterapkan oleh anak melalui kegiatan membaca, bermain dan mendongeng yang diselenggarakan Komunitas Hayu Maca. Dari hasil penelitian diperoleh 90\% peserta memiliki karakter baik dan menyukai kegiatan yang diadakan Komunitas Hayu Maca bahwa kegiatan yang diselenggarakan ini berpengaruh terhadap karakter para peserta yang dapat terlihat dari hasil observasi yang dilakukan pada hari Minggu tanggal 25 Februari 2018. Anak-anak memiliki karakter yang baik saat terlibat dalam semua kegiatan Komunitas Hayu Maca. Dengan demikian dari hasil penelitian dapat disimpulkan bahwa kontribusi Komunitas Hayu Maca dalam Meningkatkan Pendidikan Karakter Anak di Kota Cimahi dapat diterima.

3. Faktor penghambat dan faktor penghambat kegiatan Komunitas Hayu Maca

a. Faktor pendukung

1) Pemberian ijin dari pihak Dinas Pertamanan dan Pusat Persenjatan Arteleri Medan menjadi pendukung utama agar kegiatan Komunitas Hayu Maca dapat berjalan sesuai dengan perencanaan dan dapat dengan lancar.

2) Para anggota Komunitas Hayu Maca yang memiliki visi dan misi serta tujuan yang sama serta saling membantu memberikan ilmunya untuk para peserta yang datang ke Taman Kartini.

3) Dukungan dari warga masyarakat yang begitu antusias mengikuti seluruh rangkaian kegiatan yang diselenggarakan di Taman Kartini terutama anakanak.

b. Faktor penghambat

1) Cuaca, karena jika hujan mereka tidak dapat melaksanakan kegiatannya, buku- buku tidak dapat dipajang, acara mendongeng tidak terlaksana dan biasanya tidak ada peserta yang datang, saat cuaca tidak menentu dan sedang tidak bersahabat seperti hujan tiba-tiba.

2) Semenjak berubah nama menjadi Yayasan Komunitas Hayu Maca sejak tanggal 18 Februari 2018, Komunitas Hayu Maca membutuhkan lebih banyak personil untuk mengelola dan mengurus kegiatannya. Kekurangan anggota menjadi hambatan karena untuk melaksanakan kegiatannya diperlukan lebih banyak pengurus agar tujuan bersama yang di harapkan dapat tercapai. 
3) Diperlukan banyak biaya untuk mewujudkan kegiatan ini sehingga tidak memungkinkan untuk meminta pada para anggota sehingga komunitas Hayu Maca berinisiatif untuk membuat proposal dan mencari donatur untuk mendukung kegiatannya.

\section{DAFTAR PUSTAKA}

Abidin. 2012. Pembelajaran Bahasa Berbasis Pendidikan Karakter. Bandung : Refika Aditama, 2012.

Ardiwinata, J. S., \& Mulyono, D. (2018). Community Education in the development of The Community. Empowerment, 7(1), 25-35.

Halimah, Leli. 2016. Pengembangan Kurikulum Pendidikan Anak Usia Dini. Bandung : Falah Production, 2016.

Hasan, Engking S. 2008. Penuntun Penyusunan Proposal Penelitian dan penulisan Skripsi. Bandung : STKIP Siliwangi, 2008.

Kalida, Muhsin. 2012. Fundraising TBM. Yogjakarta : Langkrok Publishing, 2012.

Kartika, P. (2018). OPTIMALISASI PERAN MASYARAKAT DALAM PEMBERDAYAAN MASYARAKAT MELALUI PENDIDIKAN LUAR SEKOLAH. Empowerment, 4(1), 5057.

Komar, Oong. 2006. Filsafat Pendidikan Nonformal. Bandung : Pustaka Setia, 2006.

Musfiroh, Tadkiroatun. 2008. Cerdas Melalui Bermain. Jakarta : Grasindo, 2008.

Rosmawati, Wiwi. 2013. Pembentukan Karakter Dimulai Sejak Anak Usia Dini. Bandung : Omahima, 2013.

Rukanda, N., \& Kartika, P. (2018). IMPLEMENTASI PENYELENGGARAAN PELATIHAN FOTOGRAFI DI SEKOLAH TINGGI KEGURUAN ILMU PENDIDIKAN SILIWANGI BANDUNG. P2M STKIP Siliwangi, 5(1), 34-44.

Sudjana, djuju. 2001. Pendidikan Luar Sekolah. Bandung : Falah Production, 2001.

Syaodih, Nana. 2010. Metode Penelitian Pendidikan. Bandung : Remaja Rosdakarya, 2010.

Widiastuti, N., \& Kartika, P. (2018). PENERAPAN MODEL KELOMPOK USAHA KREATIF ISLAMI (KUKIS) DALAM PEMBERDAYAAN PEREMPUAN BERBASIS PONDOK PESANTREN. Empowerment, 6(2), 20-29. 